\title{
The Thoracic Surgery Residents Association: Past contributions, current efforts, and future directions
}

\author{
Alexander A. Brescia, MD, MSc, ${ }^{a}$ Xiaoying Lou, MD, ${ }^{b}$ Clauden Louis, MD, MS, ${ }^{c}$ David Blitzer, MD, ${ }^{d}$ \\ Garrett N. Coyan, MD, ${ }^{\mathrm{e}}$ Jason J. Han, MD, ${ }_{\mathrm{f}}^{\mathrm{f}}$ Justin J. Watson, MD, ${ }^{\mathrm{g}}$ and J. Hunter Mehaffey, MD, MSc, ${ }^{\mathrm{h}}$ on \\ behalf of the Thoracic Surgery Residents Association (TSRA)*
}

\section{ABSTRACT}

Objective: The Thoracic Surgery Residents Association (TSRA) is a resident-led organization established in 1997 under the guidance of the Thoracic Surgery Directors Association to represent the interests and educational needs of cardiothoracic surgery residents. We aim to describe the past contributions, current efforts, and future directions of the TSRA within a conceptual framework of the TSRA mission.

Methods: Primary review of educational resources was performed to report goals and content of past contributions. TSRA Executive Committee input was used to describe current resources and activities, as well as the future goals of the TSRA. Podcast analytics were performed to report national and global usage.

Results: Since 2011, the TSRA has published 3 review textbooks, 5 reference guides, 3 test-preparation textbooks, 1 supplementary publication, and 1 multiple-choice question bank and mobile application, all written and developed by cardiothoracic surgery trainees. In total 108 podcasts have been recorded by mentored trainees, with more than 175,000 unique listens. Most recently, the TSRA has begun facilitating trainee submissions to Young Surgeon's Notes, fostered a trainee mentorship program, developed the monthly TSRA Newsletter, and established a wide-reaching presence on Facebook, Twitter, and Instagram to help disseminate educational resources and opportunities for trainees.

Conclusions: The TSRA continues to be the leading cardiothoracic surgery resident organization in North America, providing educational resources and networking opportunities for all trainees. Future directions include development of an integrated disease-based resource and continued collaboration within and beyond our specialty to enhance the educational opportunities and career development of cardiothoracic trainees. (J Thorac Cardiovasc Surg 2021;162:917-27)

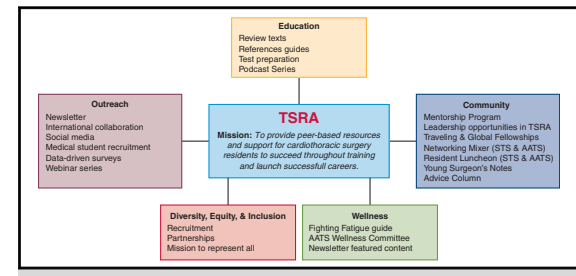

Thoracic Surgery Residents Association mission and conceptual framework.

\section{CENTRAL MESSAGE}

The TSRA remains the leading cardiothoracic surgery resident organization in North America, providing educational resources and networking opportunities for trainees past, present, and future.

\section{PERSPECTIVE}

The TSRA has made substantial contributions to CT resident training through published and electronic resources, networking events, and more recently, establishing a social media presence. Looking ahead, we aim to continue to impact trainees from medical students to advanced fellows by enhancing our educational resources, events, and collaborations to ultimately benefit our specialty and patient care

See Commentaries on pages 928 and 929.

\footnotetext{
From the a Department of Cardiac Surgery, University of Michigan, Ann Arbor Mich; ${ }^{\mathrm{b}}$ Division of Cardiothoracic Surgery, Emory University, Atlanta, Ga; ${ }^{\mathrm{c} D e}$ partment of Cardiothoracic Surgery, University of Rochester, Rochester, NY; ${ }^{\mathrm{d} D e}$ partment of Surgery, Columbia University, New York, NY; ${ }^{\mathrm{e} D e p a r t m e n t ~ o f ~}$ Cardiothoracic Surgery, University of Pittsburgh Medical Center, Pittsburgh, $\mathrm{Pa} ;{ }^{\mathrm{f}}$ Division of Cardiothoracic Surgery, University of Pennsylvania, Philadelphia, Pa; ${ }^{\mathrm{g}}$ Division of Cardiothoracic Surgery, Oregon Health \& Science University, Portland, Ore; and hivision of Thoracic and Cardiovascular Surgery, University of Virginia, Charlottesville, Va.

Dr Brescia is supported by the National Research Service Award postdoctoral fellowship (no. 5T32HL076123).
}

\footnotetext{
* The 2019-2020 TSRA Executive Committee includes Xiaoying Lou, MD, Justin J. Watson, MD, Alexander A. Brescia, MD, MSc, Heidi J. Reich, MD, J. Hunter Mehaffey, MD, MSc, Clauden Louis, MD, MS, Garrett N. Coyan, MD, MS, Jordan P. Bloom, MD, Jason J. Han, MD, David Blitzer, MD, and Anthony B. Mozer, MD. Received for publication April 17, 2020; revisions received Aug 9, 2020; accepted for publication Aug 23, 2020; available ahead of print Aug 31, 2020.

Address for reprints: Alexander A. Brescia, MD, MSc, Department of Cardiac Surgery, University of Michigan, Frankel Cardiovascular Center, 1500 E Medica Center Dr, Ann Arbor, MI 48109 (E-mail: abrescia@med.umich.edu). 0022-5223/\$36.00

Copyright (c) 2020 by The American Association for Thoracic Surgery https://doi.org/10.1016/j.jtcvs.2020.08.086
} 


\section{Abbreviations and Acronyms \\ AATS = American Association for Thoracic Surgery \\ ABTS $=$ American Board of Thoracic Surgery \\ COVID-19 = coronavirus disease 2019 \\ $\mathrm{CT}=$ cardiothoracic \\ $\mathrm{EC}=$ Executive Committee \\ STS = Society of Thoracic Surgeons \\ TSDA $=$ Thoracic Surgery Directors \\ Association \\ TSRA $=$ Thoracic Surgery Residents \\ Association \\ TSSMN $=$ Thoracic Surgery Social Media Network \\ WTS $=$ Women in Thoracic Surgery}

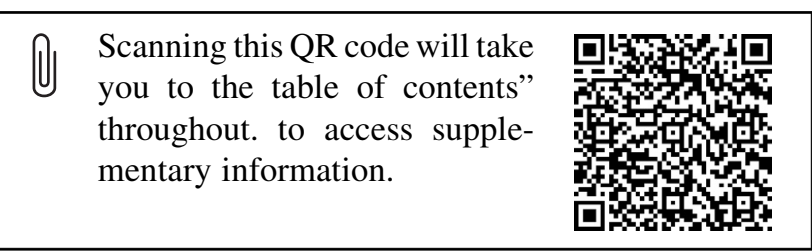

The Thoracic Surgery Residents Association (TSRA) is a trainee-led organization established in 1997 under the guidance of the Thoracic Surgery Directors Association (TSDA) to represent the interests and needs of cardiothoracic surgery residents. Dr Mark B. Orringer, former President of the Society of Thoracic Surgeons (STS) in 2001-2002 and President of the TSDA in 1997, was instrumental in forming the TSRA in coordination with its first President, Dr Michael S. Mulligan, then a thoracic surgery resident at the University of Michigan (Table 1). A governing infrastructure and method of representation through the TSDA were established in addition to monthly phone meetings and in-person meetings initiated in conjunction with the annual meetings of the STS, American Association for Thoracic Surgery (AATS), and the American College of Surgeons.

Over the past 23 years, the TSRA has remained steadfast to its original mission of supporting the education of cardiothoracic surgery trainees while also significantly evolving as an organization. A small group that began through a conversation between an academic leader and his trainee has expanded into an organization with international reach. The TSRA is led by a 12-person Executive Committee (EC), headed by officer positions including President, Vice President, Secretary, Treasurer, and Immediate Past President, as well as committee Chair positions for each of its Projects, Education, Membership, and Communications committees. The scope of TSRA activities, which are generally collaborative, have also grown, involving the promotion of trainee advocacy, networking, wellness, and career advancement as well as providing educational resources with ongoing impact.

In this report, we aim to describe the past contributions, current efforts, and future directions of the TSRA. We review the TSRA's past productivity and propose how these accomplishments inform the current activities and future plans for the organization within a conceptual framework centered around the TSRA mission.

\section{METHODS}

This report did not involve any human subjects research and therefore did not undergo review by a regulatory body.

\section{Educational Resources}

TSRA educational resources typically undergo multiple rounds of peer review as well as faculty review before publication (Table E1). Our current standard process includes each chapter to be written by a mentee (trainee) and mentor (faculty) tandem, followed by peer review by members of the TSRA EC at 3 levels: a section editor, primary editor, and copy editor for each educational resource. Primary review of educational resources to provide data used in writing this manuscript was performed by all manuscript authors.

Details regarding sales of educational resources and publication dates were gathered from organizational records on Amazon (Amazon.com, Inc, Seattle, Wash) and iTunes (Apple, Cupertino, Calif). Published resources were divided into 3 categories: review texts, reference guides, and test preparation.

\section{Activities and Events}

Input from current and past members of the TSRA EC was compiled to describe TSRA resources and activities. Future directions and goals of the TSRA were collected by members of the current TSRA EC and described in detail here by the authors.

\section{Podcast Statistical Analysis}

Web-based podcast analytics were used to collect usage statistics from SoundCloud (SoundCloud Limited, Berlin, Germany). Individual podcast usage was quantified on a per-listen basis and reported from series inception (August 2016) through December of 2019. Geographical location of podcast listens was obtained via Internet Protocol address tracking performed by SoundCloud.

\section{RESULTS}

The efforts undertaken by the TSRA center around our mission and can be broadly classified into the 5 domains: education, outreach, community, DEI (ie, diversity, equity, and inclusion), and wellness (Figure 1).

\section{Educational Resources}

Since 2011, the TSRA has published 3 review textbooks, 5 reference guides, 3 test preparation textbooks, 1 multiplechoice question bank and mobile application, and 1 supplementary publication (Figure 2 and Table 2).

Review textbooks. The TSRA Review of Cardiothoracic Surgery was developed by Joseph Turek and Carlos Mery to provide cardiothoracic trainees with a concise analysis 
TABLE 1. Thoracic Surgery Residents Association (TSRA) Presidents (1997-2020)

\begin{tabular}{|c|c|c|c|}
\hline Number & Name & Academic year & Institution \\
\hline 1 & Michael Mulligan, MD & 1997-1998 & University of Michigan \\
\hline 2 & W. Scott Arnold, MD & 1998-1999 & University of Virginia \\
\hline 3 & Antonio Laudito, MD & 1999-2001 & Jackson Memorial Hospital \\
\hline 4 & Jorge D. Salazar, MD & 2001-2002 & Johns Hopkins Hospital \\
\hline 5 & Richard Lee, MD, MBA & $2002-2003$ & Washington University in St Louis \\
\hline 6 & Grayson H. Wheatley III, MD & 2003-2004 & University of Texas Southwestern \\
\hline 7 & John R. Mehall, MD & 2004-2005 & University of Cincinnati \\
\hline 8 & D. Michael McMullan, MD & $2005-2006$ & University of Washington \\
\hline 9 & Daniel J. Boffa, MD & 2006-2007 & Cleveland Clinic \\
\hline 10 & Faraz Kerendi, MD & $2007-2008$ & Emory University \\
\hline 11 & Bret A. Mettler, MD & 2008-2009 & University of Virginia \\
\hline 12 & Joseph W. Turek, MD, PhD & 2009-2010 & Duke University \\
\hline 13 & Carlos M. Mery, MD, MPH & 2010-2011 & University of Virginia \\
\hline 14 & Jason A. Williams, MD & 2011-2012 & Duke University \\
\hline 15 & Tom C. Nguyen, MD & $2012-2013$ & New York Presbyterian Hospital-Columbia \\
\hline 16 & David D. Odell, MD, MMSc & 2013-2014 & University of Minnesota \\
\hline 17 & Damien J. LaPar, MD, MSc & 2014-2015 & University of Virginia \\
\hline 18 & Dustin M. Walters, MD & 2015-2016 & University of Washington \\
\hline 19 & Elizabeth H. Stephens, MD, PhD & 2016-2017 & New York Presbyterian Hospital-Columbia \\
\hline 20 & Andrew B. Goldstone, MD, PhD & 2017-2018 & University of Pennsylvania \\
\hline 21 & Peter Chen, MD & 2018-2019 & University of Texas-Houston \\
\hline 22 & Xiaoying Lou, MD, MS & 2019-2020 & Emory University \\
\hline 23 & Alexander A. Brescia, MD, MSc & $2020-2021$ & University of Michigan \\
\hline
\end{tabular}

of the field. The material is authored by more than 50 residents and organized into 4 sections: General Thoracic, Adult Cardiac, Congenital Cardiac, and Cardiothoracic Trauma and Critical Care. The first edition was published in August 2011 and was a popular study resource for residents preparing for rotations. Damien LaPar later led an update to the text and published its second edition in January 2016. Both editions remain available in print, e-book, or PDF versions on Amazon.

The TSRA Primer of Cardiothoracic Surgery is an integrated educational resource that is designed to illustrate fundamental concepts for new learners. This resource was designed by Samuel Youssef and Jason Williams to establish a foundation for students in the early stages of learning to build upon as they progress in their careers-hence, "a primer." The Primer is divided into 4 broad subjects (cardiac, congenital, thoracic, esophageal, and critical care) and numerous topics within each subject that were selected by the TSRA EC and Projects Committee. The content supplements the "prerequisite" curriculum of the TSDA and parallels some of the Level 1 "Milestones" of the ACGME guidelines. ${ }^{1}$ The Primer serves as a field-guide manual, with illustrations, outlines, and technical pearls that can be brought to the first encounter. The Primer was first published in July 2013 and is available as an e-book from the Apple bookstore.

Reference guides. TSRA Decision Algorithms in Cardiothoracic Surgery is a unique text and application, developed by residents and faculty mentors. Published in 2019, it is the most recent TSRA review text. This resource was written under the leadership of Xiaoying Lou by lead editor Clauden Louis and TSRA Past Presidents Peter Chen and Elizabeth Stephens. Each of more than 100 chapters includes an individual algorithm and provides a foundation and framework for approaching important cardiothoracic surgical decisions. This text focuses on the key clinical decisions, diagnostics, and interventions. This 4-year project was aimed at providing algorithmic pathways representing safe solutions to common diagnoses that could be used by caregivers of cardiothoracic patients. As of May 2020, 293 print and 152 Kindle e-book copies had been sold through Amazon.

The TSRA Operative Dictations in Cardiothoracic Surgery, published in 2014 and edited by Damien LaPar and David Odell, is a resource for daily surgical practice that reviews the main steps of major cardiothoracic 


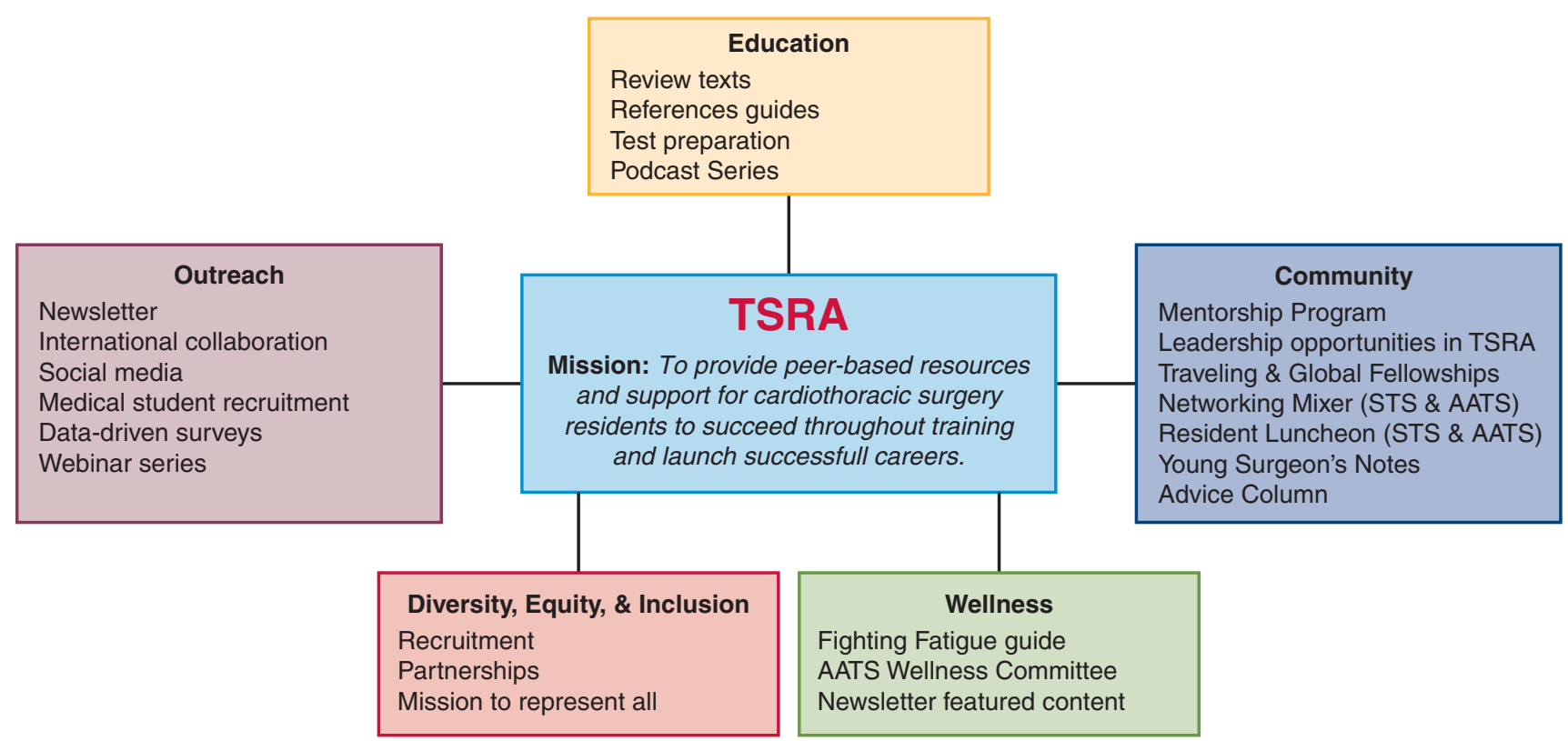

FIGURE 1. Conceptual framework for the Thoracic Surgery Residents Association (TSRA) organizational structure and efforts to support cardiothoracic trainees. STS, Society of Thoracic Surgeons; AATS, American Association for Thoracic Surgery.

surgical operations and guides their appropriate dictation and documentation. This text has been useful for both practicing surgeons and residents in training, as it provides descriptions of the most representative approach to each operation.

The TSRA Pocket Mentor, published in 2017, serves as a guide for navigating the daily residency experience.
Embarking on a residency program initiates what will be a lifelong journey to master the clinical knowledge, technical skills, and surgical decision-making necessary for a successful career in cardiothoracic surgery. The Pocket Mentor is supplemented with advice from current residents, faculty, and program directors and is available online as a free PDF.

TSRA Published Resources (2011-2019)

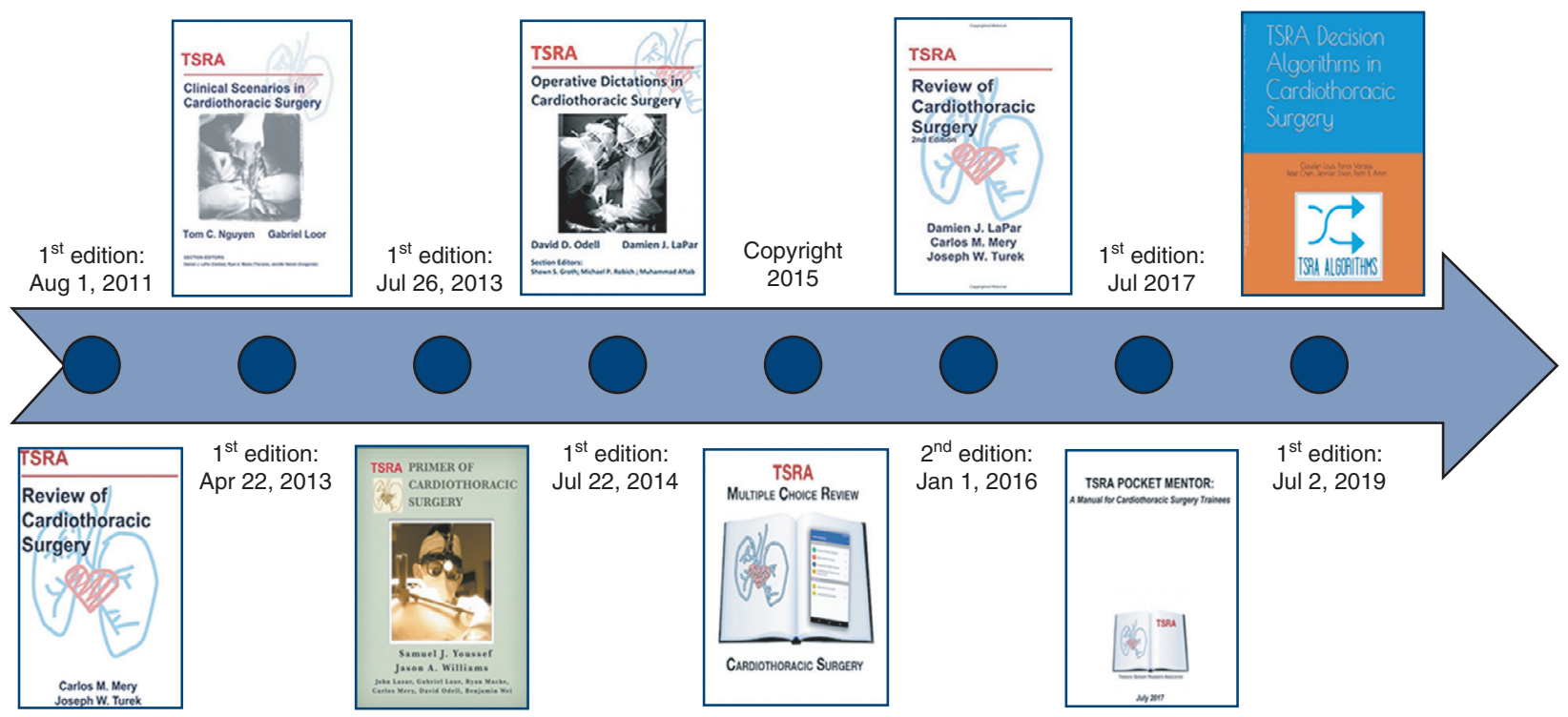

FIGURE 2. Book covers and timeline of educational resources published by the Thoracic Surgery Residents Association (TSRA) between 2011 and 2019. Dates of publication correspond to images of book covers directly above or below each publication image. 
TABLE 2. Thoracic Surgery Residents Association (TSRA) published resources (2011-2019)

\begin{tabular}{|c|c|c|c|c|}
\hline Name of resource & Editors & Edition & Release date & Format \\
\hline TSRA Review of Cardiothoracic Surgery & $\begin{array}{l}\text { Carlos M. Mery } \\
\text { Joseph W. Turek }\end{array}$ & 1 st & August 1, 2011 & $\begin{array}{l}\text { Print } \\
\text { PDF }\end{array}$ \\
\hline TSRA Clinical Scenarios in Cardiothoracic Surgery & $\begin{array}{l}\text { Tom C. Nguyen } \\
\text { Gabriel Loor } \\
\text { Damien J. LaPar } \\
\text { Ryan A. Macke } \\
\text { Jennifer Nelson }\end{array}$ & 1 st & April 22, 2013 & $\begin{array}{l}\text { Print } \\
\text { E-book } \\
\text { Phone app }\end{array}$ \\
\hline TSRA Primer of Cardiothoracic Surgery & $\begin{array}{l}\text { Samuel J. Youssef } \\
\text { Jason A. Williams }\end{array}$ & 1 st & July 26,2013 & Print \\
\hline TSRA Operative Dictations in Cardiothoracic Surgery & $\begin{array}{l}\text { David D. Odell } \\
\text { Damien J. LaPar } \\
\text { Shawn S. Groth } \\
\text { Michael P. Robich } \\
\text { Muhammad Aftab }\end{array}$ & 1st & July 22,2014 & $\begin{array}{l}\text { Print } \\
\text { E-book }\end{array}$ \\
\hline $\begin{array}{l}\text { TSRA Multiple Choice Review of } \\
\text { Cardiothoracic Surgery }\end{array}$ & Clauden Louis & Iterative & $\begin{array}{l}\text { Version } 2.0 \text { for iOS } \\
11.0 \text { or later, } 2015\end{array}$ & $\begin{array}{l}\text { iOS and } \\
\text { Android app }\end{array}$ \\
\hline TSRA Review of Cardiothoracic Surgery & $\begin{array}{l}\text { Damien J. LaPar } \\
\text { Carlos M. Mery } \\
\text { Joseph W. Turek }\end{array}$ & 2nd & January 1,2016 & $\begin{array}{l}\text { Print } \\
\text { E-book }\end{array}$ \\
\hline TSRA Intern Survival Guide & $\begin{array}{l}\text { Xiaoying Lou } \\
\text { Elizabeth H. Stephens } \\
\text { Kevin Beers } \\
\text { Brendan Dewan } \\
\text { Vakhtang Tchantchaleishvili } \\
\text { Panos Vardas }\end{array}$ & $1 \mathrm{st}$ & $\begin{array}{l}\text { Academic year } \\
\text { 2016-2017 }\end{array}$ & Free PDF \\
\hline TSRA Pocket Mentor & $\begin{array}{l}\text { Xiaoying Lou } \\
\text { Elizabeth H. Stephens }\end{array}$ & $1 \mathrm{st}$ & July 2017 & Free PDF \\
\hline TSRA Decision Algorithms in Cardiothoracic Surgery & $\begin{array}{l}\text { Clauden Louis } \\
\text { Panos Vardas } \\
\text { Peter Chen } \\
\text { Jennifer Dixon } \\
\text { Parth B. Amin }\end{array}$ & $1 \mathrm{st}$ & July 2, 2019 & $\begin{array}{l}\text { Print } \\
\text { E-book }\end{array}$ \\
\hline TSRA Literature Review & $\begin{array}{l}\text { Clauden Louis } \\
\text { David Blitzer } \\
\text { Ernest G. Chan } \\
\text { Daniel R. Ziazadeh }\end{array}$ & Iterative & & Web-based \\
\hline TSRA Blog and Advice Column & Jason J. Han & Iterative & & Web-based \\
\hline TSRA Newsletter & Alexander A. Brescia & Monthly & January 22,2020 & $\begin{array}{l}\text { Print (biannual) } \\
\text { E-newsletter } \\
\text { (monthly) }\end{array}$ \\
\hline TSRA Clinical Scenarios in Cardiothoracic Surgery & $\begin{array}{l}\text { Justin J. Watson } \\
\text { Xiaoying Lou } \\
\text { Garrett N. Coyan } \\
\text { Alexander A. Brescia } \\
\text { Jordan P. Bloom } \\
\text { Clauden Louis }\end{array}$ & 2nd & Summer 2020 & $\begin{array}{l}\text { Print } \\
\text { E-book }\end{array}$ \\
\hline
\end{tabular}

TSRA, Thoracic Surgery Residents Association.

The Intern Survival Guide was published in 2017 and is available as a free PDF. While all of our resources provide a knowledge base for all learners, the TSRA Primer of Cardiothoracic Surgery and the TSRA Intern Survival
Guide were written specifically for junior cardiothoracic surgery residents.

Finally, in addressing the domain of wellness in the TSRA mission, the TSRA and TSDA jointly released a 
free PDF titled, "Fighting Fatigue: A Guide for Cardiothoracic Surgery Residents." This guide is intended to provide simple advice on how to prepare to work extended periods of time during the day and overnight, as well as how to recover from working nights in the most efficient and effective way.

Test-preparation resources. The TSRA Clinical Scenarios in Cardiothoracic Surgery is a collection of common high-yield scenarios within the areas of General Thoracic, Adult Cardiac, and Congenital Cardiac Surgery. The resource was originally published in April 2013 under the leadership of Tom Nguyen and Gabriel Loor. Each scenario in the book was authored by a resident and reviewed by a faculty mentor. The scenarios are based on cases trainees are likely to encounter in the clinical environment and describe initial differential diagnosis, management options, operative decision-making, and postoperative care. This resource is intended to improve clinical decision-making, detail case-based surgical technique, increase medical knowledge, and promote critical thinking. The first edition review is currently available in print or as an e-book on Amazon or through iTunes as an application.

The TSRA Multiple Choice Review mobile application allows users to test their knowledge by answering multiple-choice questions spanning adult cardiac, congenital, and general thoracic surgery, as well as trauma/critical care. Each of these sections is subdivided into categories with approximately 10 questions per subject with 588 questions total. Questions can be reset to allow the user to repeat the questions as needed. More recently, the online TSRA Question Bank was developed by Clauden Louis as an update to the existing mobile application. This resource uses FRED software simulation, ${ }^{2}$ which closely mimics the format of professional standardized questions banks. ${ }^{3}$ Available on both computer and mobile browsers, the questions have been recently updated by peer-to-peer submissions and allows for continued future updates for quality and accuracy. The question bank is currently available to all trainees free of charge, and more 200 medical students, trainees, and faculty are members of the TSRA Question Bank.

TSRA podcast series. The TSRA Podcast Series is a collection of digital audio episodes produced and recorded by cardiothoracic surgery residents collaborating with faculty mentors covering a broad range of topics within cardiothoracic surgery. The series was initially launched in August of 2016 under the leadership of Elizabeth Stephens. Each episode is based on a specific topic following the format of TSRA Clinical Scenarios and features a resident interviewing expert faculty about case management within the given topical area. The TSRA currently houses the free podcast library on Soundcloud (https://soundcloud.com/ tsrapodcast). The account consists of 108 unique podcasts (Table E2) with 175,359 all-time listens as of July 15, 2020 (Figure 3). This resource has been used by trainees spanning 50 countries ranging from 65 listens in Romania and Iran to 134,478 in the United States as of July 15, 2020 (Figure 4).

Young Surgeon's Notes. Young Surgeon's Notes was originally developed as a section of the Journal of Thoracic and Cardiovascular Surgery (JTCVS), specifically written for and by young surgeons on topics salient to their early experiences. In 2018, under the leadership of Richard D. Weisel, editor-in-chief, and JTCVS education editors, James I. Fann, Ara A. Vaporciyan, and Stephen C. Yang, the Journal expanded the definition of young surgeons to include cardiothoracic trainees. The TSRA became a collaborator in both soliciting submissions for and promoting articles published in this section. The first article, titled, "See One-Practice-Do One-Practice-Teach One-Practice: The Importance of Practicing Outside of the Operating Room in Surgical Training," by Han and colleagues was published in $2018,{ }^{4}$ followed by 2 more trainee-focused articles in its first year. ${ }^{5,6}$ Following up on its initial successes,

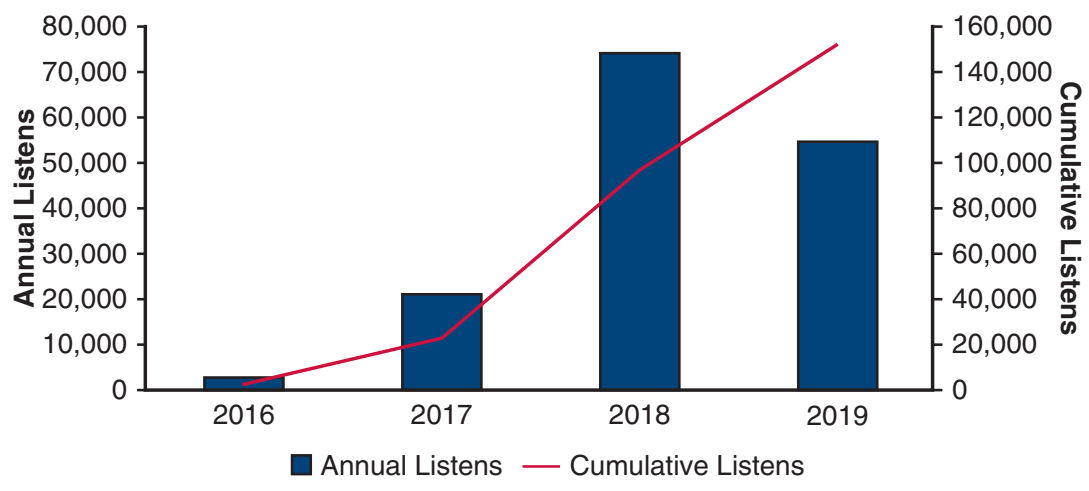

FIGURE 3. Thoracic Surgery Residents Association podcast listens over time (2016-2019). Blue columns indicate annual podcast listens each year (leftsided y-axis) and the red line indicates cumulative podcast listens over time (right-sided y-axis). 


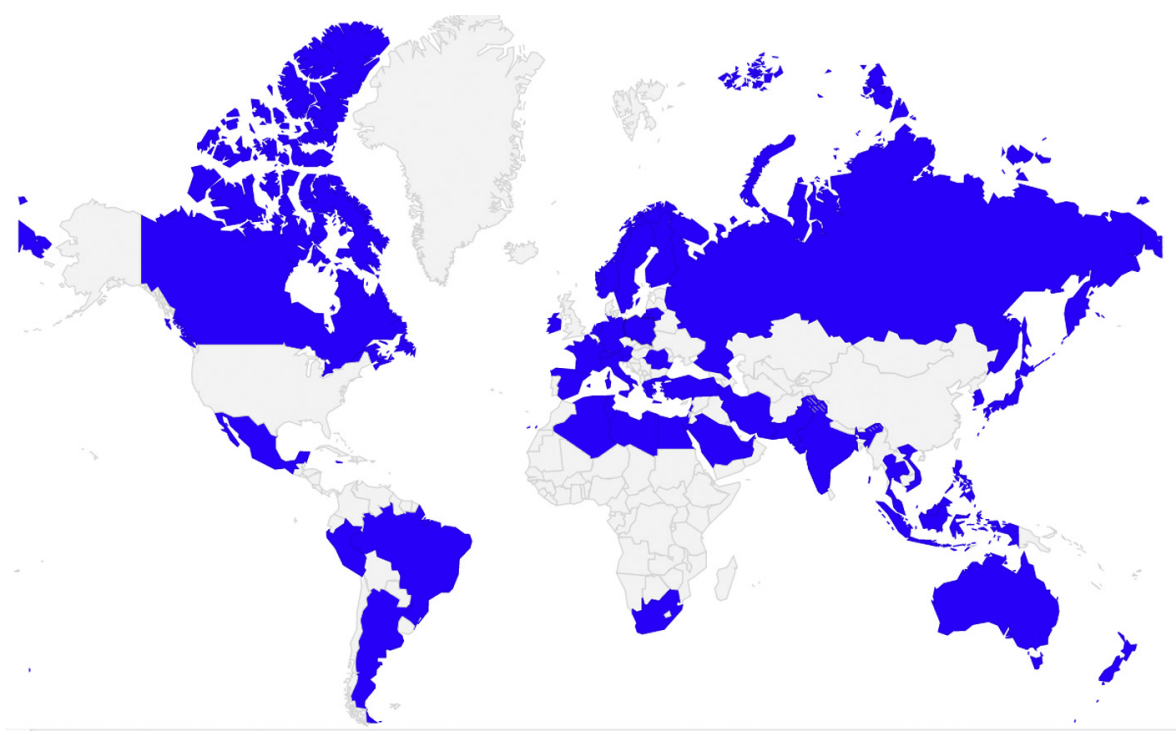

FIGURE 4. Global map showing countries with at least 1 Thoracic Surgery Residents Association podcast stream (blue). Range 174-123,339 (FinlandUnited States). Data as of March 29, 2020.

the TSRA website created its own Young Surgeon's Notes section in 2019, as a forum for publication of various types of articles pertinent to trainees' experiences. This initial Young Surgeon's Note entry ${ }^{4}$ and a subsequent TSRA survey on barriers to technical skills training have enhanced TSRA efforts to inform and improve simulation efforts in our specialty.

The tradition of publishing an annual Presidential Address began with Xiaoying Lou in 2019, with her address titled, "Preserving the Passion in Cardiothoracic Surgery Training." The Advice Column series was also developed in 2019, as a place where trainees can seek advice from a committee of established surgeons and mentors. ${ }^{8}$ The first topic of the series, "How should trainees prepare for each case to perform well and also to get as much as we can out of it?" compiled advice from 4 faculty surgeons at various stages of their careers, and was widely publicized.

\section{Activities and Events}

The TSRA Mentorship Program was created in 2015 to promote peer-to-peer mentorship. In 2017 under the leadership of Andrew Goldstone, the TSRA Membership Committee increased efforts through e-mail and social media communication to enhance participation among trainees of all levels: from first-year medical students to advanced fellows. Participants were encouraged to serve as both mentors and mentees at different stages of the pathway to becoming a cardiothoracic surgeon. The revamped Mentorship Program increased its participation from 38 trainees in 2017-2018 to 81 trainees in 2018-2019.

At the annual STS and AATS national meeting, the TSRA hosts its signature TSRA Resident Mixer. This 2-hour event is typically held on a Monday afternoon and takes place at an outside venue within walking distance from the convention center. The Mixer provides an important networking opportunity for trainees outside of the more formal, structured conference sessions. This networking forum not only strengthens collaborative efforts among trainees but also engages and recruits medical students and general surgery residents interested in the field. Attendance for this event has doubled yearly with the 2020 STS TSRA Mixer, including more than 100 trainees.

For nearly 2 decades, the TSRA has collaborated with both the STS and AATS to co-host resident luncheons at their respective annual meetings. The STS/TSRA Resident Luncheon is traditionally held on the Sunday of the annual STS conference and is headlined by a faculty keynote speaker voted on by the TSRA EC, most recently Dr Gorav Ailawadi, who delivered "Surgical Mentorship" at the 67th Annual STS meeting in New Orleans. Trainee luncheon attendees are joined by approximately 30 to 40 faculty from adult cardiac, general thoracic, and congenital subspecialties to participate in themed discussion topics relating to cardiothoracic trainee education in conjunction with the keynote address. The TSRA has also co-hosted a luncheon during the AATS, typically on the Sunday or Monday of the annual AATS conference. The most recent iteration of this luncheon at the 99th Annual AATS meeting in Toronto was titled, "AATS/TSRA Preparing Yourself for an Academic Career Luncheon Session" and included a series of speakers and panel discussions about early career decisions.

Since the emergence of coronavirus disease 2019 (COVID-19) in March 2020, the TSRA has initiated 2 virtual events for students and trainees. In April 2020, the 
TSRA EC hosted an informal teleconference of all students and trainees to discuss the impact of COVID-19 at their respective institutions, which resulted in an insightful discussion with international participation. In addition, TSRA leadership in May 2020 organized and took part in an STS Webinar "Cardiothoracic Surgery in the COVID Crisis: Impact on Residency and Training," which included a panel of trainees, program directors, and leadership from the American Board of Thoracic Surgery (ABTS) and TSDA.

\section{Social Media}

The TSRA first extended beyond website and e-mail communication and into social media by establishing a Facebook page in 2012. As the primary avenue of communication with international trainees, the Facebook page has since accumulated more than 2300 followers and 2300 "likes." The Facebook page has been an important medium to attract and support international trainees to take part in TSRA activities at national meetings and download or purchase TSRA educational resources. During the 2017-2018 academic year, the Communications Committee prioritized establishing a presence on Twitter (@TSRA_official) and has increased its following to more than 1700 people. Most recently, the TSRA has also added an Instagram account (tsra_official), LinkedIn account, and YouTube channel in an effort to build its network and reach the widest audience possible. These social media tools are used to disseminate TSRA announcements, advertise educational resources, promote resident events and achievements, as well as interact with the broader cardiothoracic surgery community.

In January 2020, the TSRA published the inaugural issue of a monthly TSRA Newsletter, both electronically and in print (Figure 5). Newsletter content includes rotating TSRA announcements, trainee opportunities, and featured content sections, as well as standard sections including Key Abstract Submission Deadlines \& Conference Dates, Manuscript of the Month with author interviews, a Diagnostic/Board Prep challenge with sample questions from the TSRA Question Bank, an updated TSRA Educational Resources index, TSRA Advice/Young Surgeon's Notes column, and Featured Podcast. Leads for each section collaborate with the Editor and TSRA EC to produce content. A wellness-themed issue in May 2020 included a letter to trainees, featured podcast, and Manuscript of the Month all addressing the topic of wellness in cardiothoracic surgical training. Under the leadership of Xiaoying Lou, Alex Brescia began as the first Editor of the Newsletter.

These recent developments through the TSRA Mentorship Program, Newsletter content highlighting base knowledge and opportunities for growth, and social media presence on Twitter, Facebook, and Instagram have been instituted to better meet the needs of younger cardiothoracic trainees, who incorporate a large proportion of our membership since the establishment of integrated pathway programs. As cardiothoracic surgery training has undergone a paradigm shift with the introduction of the integrated pathway, the TSRA Executive Committee leadership has also undergone a paradigm shift, with representation of both junior and senior trainees from both integrated and traditional pathways.

\section{DISCUSSION}

Over the past decade, the TSRA has made substantial contributions to the cardiothoracic surgery community by publishing educational resources, hosting networking activities and events, as well as building a social media presence as a representative organization for cardiothoracic (CT) surgery trainees. The TSRA is committed to updating and maintaining these resources and opportunities while integrating our educational material to ease use for trainees, and enhancing collaboration with other leading organizations in our specialty.

\section{Updates, Evaluation, and Integration of Educational Resources}

Currently, the TSRA EC is working on the second edition of TSRA Clinical Scenarios in Cardiothoracic Surgery, given its immense popularity among trainees. The second edition will feature updated scenarios, as well as several new topics to provide a more comprehensive and contemporary selection of scenarios for review. The second edition is currently undergoing copy editing and is projected for publication in August 2020. In addition, the TSRA has expanded the TSRA Literature Review website with a blog-style review of the seminal work published in the field of cardiothoracic surgery and its subspecialties. The purpose of this work is to effectively summarize previous studies in the field that guide today's perioperative decision-making, as well as stay abreast of the newest and most exciting literature as it is released.

In addition to published textbooks, the TSRA continues to administer trainee-created surveys. The system of survey submission recently was modified to occur on a rolling basis, instead of an annual survey during the TSDA in-training examination. These survey ideas are elicited and administered approximately quarterly to continue to enhance the body of literature on resident training stemming from TSRA surveys. ${ }^{9-26}$

The TSRA Podcast Series continues to expand and recruit new contributors through the Projects Committee. Career development, ethics, and adjunct practice areas are currently being incorporated into the series to expand the scope of topics relevant to current trainees. Future developments within the TSRA Podcast Series include the addition of debate-style podcasts, addition of video and media content to the series, and restructuring the storage of the current podcast library to contain cohesive playlists for topical 


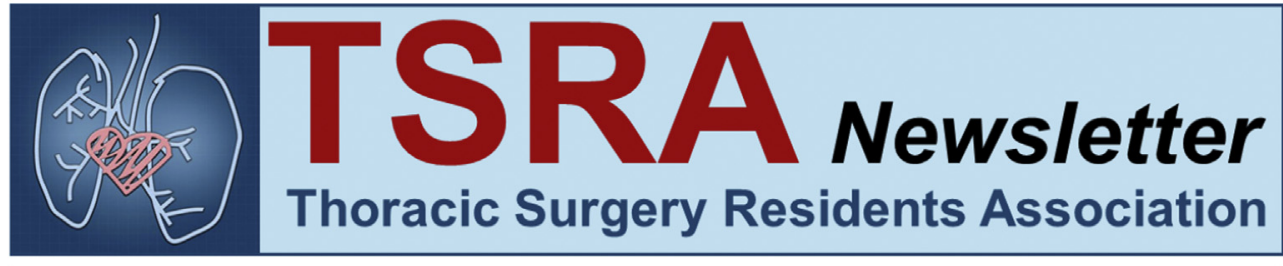

TSRA Announcements and Deadlines

All students and trainees welcome at TSRA events at STS Medical students, residents, fellows, and super fellows attending the STS Annual Meeting are encouraged to attend all STS and TSRA Resident events listed in this Newsletter!

Get involved!

To get involved with a TSRA Committee, contact Chairs for more details: Projects: Clauden Louis at clauden_louis@urmc.rochester.edu Education: Hunter Mehaffey at JHM9T@hscmail.mcc.virginia.edu Membership; Jordan Bloom at jpbloom@partners.org Communications: Alex Brescia at abrescia@med.umich.edu

Find us on social media

Connect with the TSRA through Facebook, Instagram (tsra official), and Twitter (@TSRA_official) and highlight trainee excellence at \#STS2020!

Inaugural TSRA Presidential Address:

Preserving the Passion in Cardiothoracic Surgery Training By: Xiaoying Lou, 2019-2020 TSRA President

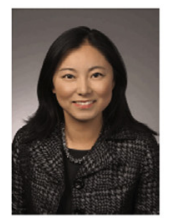

I remember the awe of feeling the human heart beating in my palm for the first time. was in high school in impressionable, mesmerized by its beauty, its persistent drumming, and the sense of purpose and commitment of the team around me working towards a common goal. knew then that cardiothoracic surgery was what I wanted to do with my life.

Continue reading on Page $3 .$.

\section{TSRA Advice Column}

By: Jason Han

Each month, we will pose a question on the minds of trainees to some of our favorite faculty mentors. Our inaugural Advice column includes mentor responses to the following question:

How should trainees prepare for each case to perform well and also to get as much as we can out of it?

Continue reading on Page 4 ...

\section{Manuscript of the Month}

By: Jordan Bloom

Objective Measure of Learning Curves for Trainees in Cardiac Surgery via Cumulative Sum Failure Analysis

Elizabeth D. Krebs, MD, MSc, William Z. Chancellor, MD, Robert B. Hawkins, MD, MSc, Jared P. Beller, MD, J. Hunter Mehaffey, MD, MSc, Nicholas R. Teman, MD, Gorav Ailawadi, MD, Leora T. Yarboro, MD

Read about this manuscript and an author interview on Page 4.

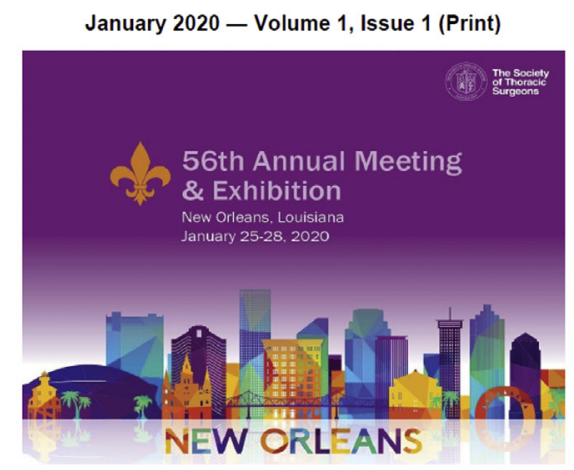

\section{Resident Events at STS}

STS Residents Symposium:

Transition from Training to Practice

Sunday, Jan 26th 10:00am-12:00 pm in Rivergate Room

STS Residents Luncheon

Sunday, Jan 26th 12:00-12:45pm in Mosaic Lounge

Jeopardy World Championship

Sunday, Jan 26th 4:45pm in the Exhibit Hall

TSRA Resident Luncheon

Monday, Jan 27th 12:15-1:15pm in Rivergate Room Keynote: Gorav Ailawadi, MD: "Surgical Mentorship"

\section{TSRA Resident Mixer}

Monday, Jan 27th 4:30-6:30pm

Cochon Restaurant

930 Tchoupitoulas St., Suite A

New Orleans, LA, 70130

TSRA Awards Presentation

Tuesday, Jan 28th 9:30-9:45am in Great Hall A-D TSRA Socrates Award TSRA McGoon Award TSRA/STS Traveling Fellowship TSRA/STS Global Outreach Fellowship

Beyond Burnout: What You Should Know and Do Going Forward

Tuesday, Jan 28th 1:00-3:00pm in Room 208

FIGURE 5. Cover page of the inaugural Thoracic Surgery Residents Association (TSRA) Newsletter released in print on January 27, 2020, at the TSRA Resident Luncheon at the Society of Thoracic Surgeons (STS) 56th Annual Meeting. An electronic version was also disseminated to TSRA membership on January 22, 2020 via e-mail.

areas that would make searching the TSRA podcast library easier. The Podcast Series is also transitioning from a paradigm of on-site recording with individual smartphones to an online podcast audio recording platform that will improve audio quality and allow for residents to conduct interviews with multiple faculty members at distant institutions, expanding opportunities for involvement and collaboration.

Importantly, the organization will focus on evaluating the impact of specific TSRA resources. Data from our most recently publication (Decision Algorithms) indicate that there is substantial interest in TSRA content, and perhaps counterintuitively, nearly double the number of print copies compared with Kindle e-book copies has been bought. While metrics including book and mobile application sales and podcast listens are available, these data do not specifically address which resources trainees find most beneficial and the impact of using specific resources on the in-training examination, ABTS Board examination pass rates, job 
placement and type, and perceived deficiencies in these resources. These data will be a focus of future TSRA efforts.

The TSRA plans to develop an integrated disease-based educational resource, which may include linking existing resources such as the Review and Clinical Scenarios with TSRA Podcasts, Decision Algorithms, Literature Review, and Question Bank. This major effort will be driven primarily through data provided by current trainees and recent graduates to identify the highest yield existing resources and modes of dissemination which will inform the development of an integrated resource, with web, mobile, and print versions to accommodate all types of learners. Throughout all projects involving updating existing or creating new resources, the TSRA is dedicated to a framework of trainee authorship under the mentorship of board-certified faculty for the purposes of fostering a mentor-mentee relationship and assuring quality.

\section{Expansion of Activities and Events}

With 2 years of survey data from the TSRA Mentorship Program thus far, the EC will continue to collect responses for 3 more years before reporting a 5-year experience of this program. A separate survey of nationwide trainees addressing attitudes toward mentorship administered by the TSRA was presented at the 67th STS Annual Meeting and accepted for publication by The Annals of Thoracic Surgery. These data will be used to expand and improve the Mentorship Program moving forward.

The TSRA is committed to continued expansion of the TSRA Resident Mixer at the STS and AATS annual meetings. This networking event has evolved to now more frequently include engaged medical students and general surgery residents, in addition to current cardiothoracic residents. These efforts have been made deliberately by collaborating with the Looking to the Future Program at the STS and the Member for a Day Program at the AATS, both attracting top medical students, general surgery residents, and junior cardiothoracic residents. In addition, planning for the Mixer now explicitly includes coordination with Women in Thoracic Surgery (WTS) to assure that all students and trainees have the opportunity to attend both networking events. These collaborative efforts will not only benefit TSRA membership and involvement, but will help promote and strengthen our specialty.

\section{Social Media Growth, Partnerships, and Diversity}

The impact of social media on the cardiothoracic surgery community has increased precipitously over the past 2 to 4 years through initiatives and organizations including the Cardiothoracic Surgery Network (CTSNet, @ctsnetorg) and the Thoracic Surgery Social Media Network (TSSMN, @ TSSMN). The profound impact of the TSSMN including use of its hashtag \#TSSMN, moderated TweetChats, and TSSMN Tweeter iTunes App has included millions of Twitter impressions and thousands of application downloads as a collaborative effort through The Annals of Thoracic Surgery and The Journal of Thoracic and Cardiovascular Surgery. ${ }^{27}$ The impact and importance of social media and virtual engagement has increased substantially as a result of the COVID-19 pandemic, as cardiothoracic trainees have been forced to pursue virtual platforms for some elements of training. ${ }^{28-30}$ The TSRA plans to develop a series of simulation videos to be potentially featured in collaboration with AATS Online or on the TSRA YouTube channel. In addition, the TSRA will specifically be hosting 3 Webinars in the summer and fall of 2020, focused on (1) the virtual application process for medical students (August), (2) navigating the job search during a pandemic for senior trainees (September), and (3) the virtual application process for general surgery residents (October). These webinars will feature participation from medical students, cardiothoracic trainees, faculty leaders from academic and private practices, and program directors and be subsequently posted on the TSRA YouTube channel.

TSRA collaboration is not limited to the cardiothoracic surgery specialty. While the organization has existing relationships with Chest and the American College of Cardiology, future goals include developing sustainable relationships and pathways for CT trainees to join the American College of Cardiology Fellows-in-Training program and encourage more robust dialogue between cardiac surgery and cardiology at the trainee level. Similarly, the TSRA will be focused on increasing in-person and digital interactions with Chest and the American College of Surgeons. Within our specialty, the TSRA remains committed to continued collaboration with its parent organization the TSDA and the 2 major North American societies, the STS and AATS. The TSRA will aim to collaborate with the TSDA, STS, and AATS to enhance cardiothoracic trainee educational tools, with a focus on user-friendly convenience and adaptability to keep pace with our evolving field.

Diversity, equity, and inclusion is an important focus of our organization, which we incorporate into all of our activities and operations. We specifically aim to promote diversity by focusing on recruitment and partnerships. Recruiting diversity not only applies to the TSRA EC leadership but to the applicants entering cardiothoracic surgery through medical student outreach. In addition, we plan to amplify our informal collaboration with the WTS by establishing an ex officio position on our EC for a WTS member each year to maintain regular communication and collaboration. We are dedicated to promoting diversity in all initiatives and look forward to additional recruitment and partnerships in the future. 


\section{CONCLUSIONS}

The TSRA has made substantial contributions to the education of CT surgery trainees through published resources, sponsored activities and events, and establishing a social media presence. Over the next decade, we aim to impact a broad range of trainees from medical students to advanced fellows by enhancing our educational resources, events, and collaborations to ultimately improve our specialty and cardiothoracic surgical patient care while fulfilling our mission.

\section{Disclosures}

TSRA resources are provided as a basic guideline for the study of cardiothoracic surgery and should be used in conjunction with other educational references and resources. As stated within each resource, these tools should not be construed as definitive study guides for either the TSDA In-Training Exam or the ABTS Part I (written) and Part II (oral) Certification Examinations. The TSRA makes no claims regarding any education resource's value in preparing for, or its contribution toward performance on, either the TSDA In-Training Exam or the ABTS Certification Exams. TSRA resources are educational tools only and any medical decisions should be made only after discussions with appropriate healthcare providers.

\section{Conflict of Interest Statement}

The authors reported no conflicts of interest.

The Journal policy requires editors and reviewers to disclose conflicts of interest and to decline handling or reviewing manuscripts for which they may have a conflict of interest. The editors and reviewers of this article have no conflicts of interest.

\section{References}

1. Accreditation Council for Graduate Medical Education. Milestones. Available at: https://www.acgme.org/What-We-Do/Accreditation/Milestones/Overview. Accessed April 6, 2020.

2. FREDv2 | What Runs | CodeWeavers. CodeWeavers, Inc; 2012. Available at: https://www.codeweavers.com/compatibility/crossover/fredv2. Accessed April 10,2020 .

3. NBME Orientation; 2020. Available at: https://orientation.nbme.org/Launch/ USMLE/STPF1. Accessed April 10, 2020.

4. Han JJ, Patrick WL. See one-practice-do one-practice-teach onepractice: the importance of practicing outside of the operating room in surgical training. J Thorac Cardiovasc Surg. 2019;157:671-7.

5. Coyan G, Emerel L, Sciortino C. Establishing an academic niche in cardiothoracic surgery: the earlier the better. J Thorac Cardiovasc Surg. 2019;157:2381-4.

6. Stephens EH, Fiedler AG. Beyond \#ILookLikeASurgeon. J Thorac Cardiovasc Surg. 2018;156:1131-6.

7. Lou X. Thoracic Surgery Residents Association inaugural presidential address: preserving the passion in cardiothoracic surgery training. J Thorac Cardiovasc Surg. 2020;160:1002-3.

8. Young Surgeon's Notes | TSRA. Available at: https://www.tsranet.org/newsevents/young-surgeons-notes/. Accessed April 7, 2020.

9. Salazar JD, Lee R, Wheatley GH III, Doty JR. Are there enough jobs in cardiothoracic surgery? The Thoracic Surgery Residents Association job placement survey for finishing residents. Ann Thorac Surg. 2004;78:1523-7.
10. Wheatley GH III. Job availability for finishing cardiothoracic surgery residents Ann Thorac Surg. 2005;79:384.

11. Salazar JD, Ermis P, Laudito A, Lee R, Wheatley GH III, Paul S, et al. Cardiothoracic surgery resident education: update on resident recruitment and job placement. Ann Thorac Surg. 2006;82:1160-5.

12. Cooke DT, Kerendi F, Mettler BA, Boffa DJ, Mehall JR, Merrill WH, et al. Update on cardiothoracic surgery resident job opportunities. Ann Thorac Surg. 2010;89:1853-8; discussion 1858-9.

13. Sarkaria IS, Carr SR, MacIver RH, Whitson BA, Joyce DL, Stulak J, et al. The 2010 Thoracic Surgery Residents Association workforce survey report: a view from the trenches. Ann Thorac Surg. 2011;92:2062-70; discussion 2070-1.

14. Boffa DJ, Gangadharan S, Kent M, Kerendi F, Onaitis M, Verrier E, et al. Selfperceived video-assisted thoracic surgery lobectomy proficiency by recent graduates of North American thoracic residencies. Interact Cardiovasc Thorac Surg. 2012; 14:797-800.

15. Pham DT, Stephens EH, Antonoff MB, Colson YL, Dildy GA, Gaur P, et al. Birth trends and factors affecting childbearing among thoracic surgeons. Ann Thorac Surg. 2014;98:890-5

16. Nguyen TC, Terwelp MD, Stephens EH, Odell DD, Loor G, LaPar DJ, et al. Resident perceptions of 2-year versus 3-year cardiothoracic training programs. Ann Thorac Surg. 2015;99:2070-5; discussion 2075-6.

17. Odell DD, Macke RA, Tchantchaleishvili V, Loor G, Nelson JS, LaPar DJ, et al Resident perception of technical skills education and preparation for independent practice. Ann Thorac Surg. 2015;100:2305-12; discussion 2312-3.

18. Tchantchaleishvili V, LaPar DJ, Odell DD, Stein W, Aftab M, Berfield KS, et al Predictors of career choice among cardiothoracic surgery trainees. Ann Thorac Surg. 2015;100:1849-54; discussion 1853.

19. Stephens EH, Odell D, Stein W, LaPar DJ, DeNino WF, Aftab M, et al. A decade of change: training and career paths of cardiothoracic surgery residents 2003 to 2014. Ann Thorac Surg. 2015;100:1305-13; discussion 1313-4.

20. Tchantchaleishvili V, LaPar DJ, Stephens EH, Berfield KS, Odell DD, DeNino WF. Current integrated cardiothoracic surgery residents: a Thoracic Surgery Residents Association survey. Ann Thorac Surg. 2015;99:1040-7.

21. Robich MP, Flagg A, LaPar DJ, Odell DD, Stein W, Aftab M, et al. Understanding why residents may inaccurately log their role in operations: a look at the 2013 in-training examination survey. Ann Thorac Surg. 2016;101:323-8.

22. Shah AA, Aftab M, Tchantchaleishvili V, LaPar DJ, Stephens EH, Walters DM, et al. Characterizing the operative experience of cardiac surgical trainees: what are residents really doing in the operating room? Ann Thorac Surg. 2016;101: 2341-9.

23. Stephens EH, Shah AA, Robich MP, Walters DM, DeNino WF, Aftab M, et al The Future of the academic cardiothoracic surgeon: results of the TSRA TSDA in-training examination survey. Ann Thorac Surg. 2016;102:643-50.

24. Stephens EH, Robich MP, Walters DM, DeNino WF, Aftab M, Tchantchaleishvili V, et al. Gender and cardiothoracic surgery training: specialty interests, satisfaction, and career pathways. Ann Thorac Surg. 2016;102:200-6.

25. Stephens EH, Walters DM, Eilers AL, Tchantchaleishvili V, Goldstone AB, Gillaspie EA, et al. Variability in integrated cardiothoracic training program curriculum. Ann Thorac Surg. 2017;103:1984-91.

26. Blitzer D, Stephens EH, Tchantchaleishvili V, Lou X, Chen P, Pattakos G, et al Risks and rewards of advanced practice providers in cardiothoracic surgery training: national survey. Ann Thorac Surg. 2019;107:597-602.

27. Luc JGY, Ouzounian M, Bender EM, Blitz A, Stamp NL, Varghese TK, et al. The thoracic surgery social media network: early experience and lessons learned. $J$ Thorac Cardiovasc Surg. 2019;158:1127-36.

28. Olive JK, Luc JGY, Cerqueira RJ, Eulert-Grehn J-J, Han JJ, Phan K, et al. The cardiothoracic surgery trainee experience during the COVID-19 pandemic: global insights and opportunities for ongoing engagement. J Thorac Cardiovasc Surg. June 25, 2020 [Epub ahead of print].

29. Boskovski MT, Hirji SA, Brescia AA, Chang AC, Kaneko T. Enhancing thoracic surgical trainee competence in the COVID-19 era: challenges and opportunities for mentorship. J Thorac Cardiovasc Surg. June 26, 2020 [Epub ahead of print].

30. Luc JGY, Archer MA, Arora RC, Bender EM, Blitz A, Cooke DT, et al. The thoracic surgery social media network experience during the COVID-19 pandemic. Ann Thorac Surg. 2020;110:1103-7.

Key Words: education, training, residents, fellows, cardiothoracic surgery education 
TABLE E1. Authorship and editorial review process statistics for recent Thoracic Surgery Residents Association published educational resources (2011-2019)

\begin{tabular}{|c|c|c|c|c|c|c|c|}
\hline Name of resource & Edition & Release date & $\begin{array}{l}\text { No. of } \\
\text { trainee } \\
\text { editors }\end{array}$ & $\begin{array}{l}\text { No. of } \\
\text { faculty } \\
\text { editors }\end{array}$ & $\begin{array}{c}\text { Rounds of } \\
\text { editorial } \\
\text { review }\end{array}$ & $\begin{array}{c}\text { No. of } \\
\text { trainee } \\
\text { authors } \\
\end{array}$ & $\begin{array}{c}\text { No. of } \\
\text { faculty } \\
\text { authors }\end{array}$ \\
\hline $\begin{array}{l}\text { TSRA Review of } \\
\quad \text { Cardiothoracic Surgery }\end{array}$ & 1 st & August 1, 2011 & 2 & 0 & 3 & 93 & 13 \\
\hline $\begin{array}{c}\text { TSRA Clinical Scenarios in } \\
\text { Cardiothoracic Surgery }\end{array}$ & $1 \mathrm{st}$ & April 22, 2013 & 6 & 0 & 3 & 77 & 74 \\
\hline $\begin{array}{l}\text { TSRA Primer of } \\
\quad \text { Cardiothoracic Surgery }\end{array}$ & 1st & July 26, 2013 & 7 & 8 & 2 & 94 & 0 \\
\hline $\begin{array}{l}\text { TSRA Operative Dictations in } \\
\text { Cardiothoracic Surgery }\end{array}$ & 1 st & July 22, 2014 & 6 & 0 & 3 & 103 & 113 \\
\hline $\begin{array}{l}\text { TSRA Review of } \\
\quad \text { Cardiothoracic Surgery }\end{array}$ & 2nd & January 1, 2016 & 6 & 2 & 3 & 62 & 0 \\
\hline TSRA Intern Survival Guide & $1 \mathrm{st}$ & Academic Year 2016-2017 & 6 & 0 & 2 & 6 & 0 \\
\hline TSRA Pocket Mentor & $1 \mathrm{st}$ & July 2017 & 2 & 0 & 2 & 11 & 4 \\
\hline $\begin{array}{l}\text { TSRA Decision Algorithms in } \\
\text { Cardiothoracic Surgery }\end{array}$ & 1 st & July 2, 2019 & 5 & 0 & 3 & 98 & 103 \\
\hline $\begin{array}{c}\text { TSRA Clinical Scenarios in } \\
\text { Cardiothoracic Surgery }\end{array}$ & 2 nd & August, 2020 & 5 & 0 & 3 & 100 & 95 \\
\hline
\end{tabular}


TABLE E2. Thoracic Surgery Residents Association recorded podcasts recorded by faculty and trainee tandems from August 15, 2016, through July 15, 2020

\begin{tabular}{|c|c|c|c|c|}
\hline Name of podcast & Trainee author & Faculty author & Institution & Date \\
\hline Type A dissection & Gregory Pattakos & Joseph Coselli & Baylor/Texas Heart & August 15, 2016 \\
\hline Transposition of great arteries & Peter Chen & Charles Fraser & Baylor/Texas Heart & August 15, 2016 \\
\hline Aortic arch aneurysm & Melissa Levack & Eric Roselli & Cleveland Clinic & September 23, 2016 \\
\hline Tracheal stenosis & Amy Fiedler & Douglas Mathisen & $\begin{array}{l}\text { Massachusetts General } \\
\text { Hospital }\end{array}$ & September 23, 2016 \\
\hline Pericardial disease & Sahar Saddoughi & Hartzell Schaff & Mayo Clinic & September 23, 2016 \\
\hline Total artificial heart & Vakhtang Tchantchaleishvili & Lyle Joyce & Mayo Clinic & September 23, 2016 \\
\hline $\begin{array}{l}\text { Hypertrophic obstructive } \\
\text { cardiomyopathy }\end{array}$ & Bobby Steffen & Nicholas Smedira & Cleveland Clinic & September 24, 2016 \\
\hline Ischemic mitral regurgitation & Sarah Schubert & Irving Kron & University of Virginia & September 28, 2016 \\
\hline Surgical treatment of Afib & Matthew Schill & Ralph Damiano & $\begin{array}{l}\text { Washington University in St } \\
\text { Louis }\end{array}$ & October 4, 2016 \\
\hline Degenerative mitral valve & Sarah Ward & Steven Bolling & University of Michigan & October 12, 2016 \\
\hline IAA/VSD & Josh Rosenblum & Kirk Kanter & Emory University & October 12, 2016 \\
\hline Transcatheter AVR & Josh Rosenblum & Vinod Thourani & Emory University & October 22, 2016 \\
\hline Ascending aortic aneurysm & Michael Kayatta & Ed Chen & Emory University & October 23, 2016 \\
\hline Complete AV canal & Luis Velasco & Richard Jonas & $\begin{array}{l}\text { Children's National Medical } \\
\text { Center }\end{array}$ & October 23, 2016 \\
\hline Transcathter AVR & Michael Kayatta & Vinod Thourani & Emory University & October 25, 2016 \\
\hline Heart failure/transplant & Castigliano Bhamidipati & Jonathan Chen & University of Washington & October 25, 2016 \\
\hline Coronary artery bypass graft & Arman Arghami & John Stulak & Mayo Clinic & November 4, 2016 \\
\hline $\begin{array}{l}\text { Pulmonary } \\
\text { Thromboendarterectomy }\end{array}$ & Trevor Upham & Michael Madani & $\begin{array}{l}\text { University of California San } \\
\text { Diego }\end{array}$ & November 4, 2016 \\
\hline Ventricular septal defect & David Blitzer & John Brown & Indiana University & November 21, 2016 \\
\hline Paraesophageal hernia & Lucia Madaraiaga & Christopher Morse & $\begin{array}{l}\text { Massachusetts General } \\
\text { Hospital }\end{array}$ & December 13, 2016 \\
\hline Coarctation of aorta & Corinne Tan & Carlos Mery & Baylor/Texas Children's & December 13, 2016 \\
\hline Tetralogy of Fallot & Elizabeth Stephens & Emile Bacha & Columbia & December 19, 2016 \\
\hline Aortic valve stenosis & Brendan Dewan & David Fullerton & University of Colorado & December 22, 2016 \\
\hline Anterior mediastinal tumors & Panos Vardas & Ken Kesler & Indiana University & December 22, 2016 \\
\hline Endocarditis & Amy Fiedler & Thoralf Sundt & $\begin{array}{l}\text { Massachusetts General } \\
\text { Hospital }\end{array}$ & December 23, 2016 \\
\hline Truncus arteriosus & Peter Sassalos & Edward Bove & University of Michigan & December 27, 2016 \\
\hline Esophageal diverticulum & Monisha Sudarshan & Shanda Blackmon & Mayo Clinic & December 28, 2016 \\
\hline Left ventricular assist device & Arman Kilic & Michael Acker & University of Pennsylvania & January 3, 2017 \\
\hline Surgical treatment of TB & Jordan Hoffman & John Mitchell & University of Colorado & January 18, 2017 \\
\hline $\begin{array}{l}\text { Creativity and innovation } \\
\text { surgery }\end{array}$ & Elizabeth Stephens & Tirone David & University of Toronto & January 25, 2017 \\
\hline Ebstein anomaly & Hampton Gray & Vaughn Starnes & $\begin{array}{l}\text { University of Southern } \\
\text { California }\end{array}$ & February 6, 2017 \\
\hline History of ECMO & K. Candis Jones & Robert Bartlett & University of Michigan & February 10, 2017 \\
\hline History of ECMO 2 & K. Candis Jones & Robert Bartlett & University of Michigan & February 12, 2017 \\
\hline $\begin{array}{l}\text { Pulmonary atresia w/VSD and } \\
\text { MAPCAs }\end{array}$ & Michael Ma & Frank Hanley & Stanford University & February 12, 2017 \\
\hline $\begin{array}{l}\text { Hypoplastic left heart } \\
\text { syndrome }\end{array}$ & Eric Feins & Pedro del Nido & Boston Children's Hospital & February 12, 2017 \\
\hline
\end{tabular}


TABLE E2. Continued

\begin{tabular}{|c|c|c|c|c|}
\hline Name of podcast & Trainee author & Faculty author & Institution & Date \\
\hline $\begin{array}{l}\text { Treatment of mycobacterial } \\
\text { lung infections }\end{array}$ & Jordan Hoffman & John Mitchell & University of Colorado & February 14, 2017 \\
\hline Aortic root aneurysm & Melissa Levack & Lars Svensson & Cleveland Clinic & March 15, 2017 \\
\hline $\begin{array}{l}\text { Atrial fibrillation and Cox } \\
\text { maze }\end{array}$ & Danielle Smith & Jim Cox & Northwestern University & March 15, 2017 \\
\hline LVOT obstruction & Charles Cole & Jim Jaggers & University of Colorado & March 16, 2017 \\
\hline Aortic regurgitation & Lori Soni & Duke Cameron & Johns Hopkins & April 4, 2017 \\
\hline Type B dissection & Colleen Pietras & Alberto Pochettino & Mayo Clinic & May 4, 2017 \\
\hline $\begin{array}{l}\text { Thoracoabdominal } \\
\text { aneurysms }\end{array}$ & David Blitzer & Joel Corvera & Indiana University & June 26,2017 \\
\hline Esophageal cancer & Doug Liou & Mark Berry & Stanford University & July 17, 2017 \\
\hline $\begin{array}{l}\text { Complex benign esophageal } \\
\text { disease }\end{array}$ & Stephania Worrell & Mark Orringer & University of Michigan & July 20, 2017 \\
\hline $\begin{array}{l}\text { Total anomalous pulmonary } \\
\text { venous return }\end{array}$ & Rachel Vanderlaan & Chris Calderone & Hospital for Sick Children & July 30, 2017 \\
\hline Esophageal perforation & Kevin Graham & Mimi Ceppa & Indiana University & August 7, 2017 \\
\hline Ex vivo lung perforation & Colleen Pietras & Edward Cantu & University of Pennsylvania & October 15, 2017 \\
\hline Patent ductus arteriosus & Justin Watson & Irving Shen & $\begin{array}{l}\text { Oregon Health and Sciences } \\
\text { University }\end{array}$ & October 15, 2017 \\
\hline Diaphragmatic plication & Nkem Aziken & Rafael Andrade & University of Minnesota & October 29, 2017 \\
\hline Chylothorax & Justin Watson & Paul Schipper & $\begin{array}{l}\text { Oregon Health and Sciences } \\
\text { University }\end{array}$ & October 30, 2017 \\
\hline Vascular Rings and Slings & Constatine Mavroudis & J. William Gaynor & University of Pennsylvania & December 4, 2017 \\
\hline $\begin{array}{r}\text { Pediatric airway } \\
\text { reconstruction }\end{array}$ & Jacob Miller & Peter Manning & $\begin{array}{l}\text { Washington University in St. } \\
\text { Louis }\end{array}$ & December 14, 2017 \\
\hline ALCAPA & David Lehenbauer & Marshall Jacobs & $\begin{array}{l}\text { Cincinnati Children's/Johns } \\
\text { Hopkins }\end{array}$ & December 14, 2017 \\
\hline $\begin{array}{l}\text { History cardiopulmonary } \\
\text { bypass }\end{array}$ & Paul Linsky & William Holman & $\begin{array}{l}\text { University of Alabama } \\
\text { Birmingham }\end{array}$ & December 14, 2017 \\
\hline ASD/PAPVR & Laura Seese & Victor Morell & University of Pittsburgh & December 14, 2017 \\
\hline $\begin{array}{l}\text { HLHS/single-ventricle } \\
\text { palliation }\end{array}$ & Claude Beaty & Richard Ohy & University of Michigan & December 21, 2017 \\
\hline $\begin{array}{l}\text { Ebstein anomaly cone } \\
\text { procedure }\end{array}$ & Garrett Coyan & Jose Da Silva & University of Pittsburgh & January 1, 2018 \\
\hline $\begin{array}{l}\text { Lung volume reduction } \\
\text { surgery }\end{array}$ & Ruben Nava & Bryan Meyers & $\begin{array}{l}\text { Washington University in St } \\
\text { Louis }\end{array}$ & February 12, 2018 \\
\hline Chest wall tumor & Robert Van Haren & Ara Vaporciyan & $\begin{array}{l}\text { University of Texas MD } \\
\text { Anderson }\end{array}$ & February 25, 2018 \\
\hline Non-small cell lung cancer & Chris Holley & Michael Weyant & University of Colorado & February 25,2018 \\
\hline Lung transplant & Corinne Tan & Gabriel Loor & Baylor College of Medicine & March 18, 2018 \\
\hline $\begin{array}{l}\text { Mitral valve repair vs } \\
\text { replacement }\end{array}$ & Daniel Enter & Patrick McCarthy & Northwestern University & March 25, 2018 \\
\hline $\begin{array}{l}\text { ECMO placement and } \\
\text { management }\end{array}$ & Amber Melvin & Sunil Prasad & University of Rochester & March 25, 2018 \\
\hline Pediatric lung transplant & Brandi Scully & Jeffrey Heinle & Baylor College of Medicine & April 11, 2018 \\
\hline $\begin{array}{l}\text { ECMO/LVAD management in } \\
\text { pediatric patient }\end{array}$ & Jacob Miller & Pirooz Eghtsady & $\begin{array}{l}\text { Washington University in St } \\
\text { Louis }\end{array}$ & April 28, 2018 \\
\hline
\end{tabular}


TABLE E2. Continued

\begin{tabular}{|c|c|c|c|c|}
\hline Name of podcast & Trainee author & Faculty author & Institution & Date \\
\hline $\begin{array}{l}\text { Surgical Scientist Career and } \\
\text { Mentorship }\end{array}$ & Elizabeth Stephens & Irving Kron & University of Arizona & May 5, 2018 \\
\hline Early career development & Panos Vardas & Vinay Badhwar & $\begin{array}{c}\text { Indiana University/West } \\
\text { Virginia University }\end{array}$ & May 16, 2018 \\
\hline Technical esophagectomy & Llitch Diaz-Gutierrez & Daniela Molena & $\begin{array}{l}\text { University of Minnesota/ } \\
\text { Memorial Sloan Kettering }\end{array}$ & May 18, 2018 \\
\hline Porcelain aorta & Jordan Bloom & Tom MacGillivary & Houston Methodist & August 23, 2018 \\
\hline ECMO cardiogenic shock & Amber Melvin & Sunil Prasad & University of Rochester & August 23, 2018 \\
\hline Post-infarct VSD & Daniel Weber & Scot Merrick & $\begin{array}{l}\text { University of California San } \\
\text { Francisco }\end{array}$ & August 23, 2018 \\
\hline Mini mitral & Robert Hawkins & Gorav Ailawadi & University of Virginia & October 24, 2018 \\
\hline Myocardial protection & Bill Regalie & Richard Shemin & $\begin{array}{l}\text { University of California Los } \\
\text { Angeles }\end{array}$ & October 24, 2018 \\
\hline Working with industry & Garrett Coyan & Robert Kormos & University of Pittsburgh & October 31, 2018 \\
\hline Pneumonectomy & Abdulihman Elnaggar & Daniel Raymond & Cleveland Clinic & November 11, 2018 \\
\hline AVR root & Jordan Bloom & Gerorge Tolis & $\begin{array}{l}\text { Massachusetts General } \\
\text { Hospital }\end{array}$ & November 20, 2018 \\
\hline Iatrogenic dissection & Matt Byler & Curtis Tribble & University of Virginia & November 20, 2018 \\
\hline Heart transplant & Michael Salna & Yoshifumi Naka & Columbia University & November 20, 2018 \\
\hline Tricuspid regurgitation & Zach Chancellor & Irving Kron & University of Arizona & November 20, 2018 \\
\hline $\begin{array}{l}\text { Ethics: CT shortage and } \\
\text { specialization }\end{array}$ & Omar Almoghrabi & Emmanuel Daon & University of Kansas & December 4, 2018 \\
\hline VATS anatomical resection & Sara Najmeh & Thomas D'Amico & Duke University & January 21, 2019 \\
\hline Double outlet right ventricle & Awais Ashfaq & Ashok Muralidaran & $\begin{array}{l}\text { Oregon Health and Science } \\
\text { University }\end{array}$ & January 26, 2019 \\
\hline $\begin{array}{l}\text { Off-pump coronary artery } \\
\text { bypass }\end{array}$ & Safi Haq & Tomas Salerno & University of Miami & February 12, 2019 \\
\hline How to publish & Michael Salna & Paul Kurlansky & Columbia University & February 12, 2019 \\
\hline Surgeon scientist & Eric Charles & Irving Kron & University of Arizona & February 12, 2019 \\
\hline Social media in CT & Jessica Luc & Mara Antonoff & $\begin{array}{l}\text { University of British } \\
\text { Columbia/MD Anderson }\end{array}$ & March 14, 2019 \\
\hline Hemi-arch vs total arch & Laura Seese & Thomas Gleason & University of Pittsburgh & April 14, 2019 \\
\hline Aortic arch aneurysm & Philip Spencer & Arminder Jassar & $\begin{array}{l}\text { Massachusetts General } \\
\text { Hospital }\end{array}$ & April 24, 2019 \\
\hline Society involvement & Josh Boys & Christine Lau & University of Virginia & May 11, 2019 \\
\hline Crashing on pump & Even Rotar & Curtis Tribble & University of Virginia & May 11, 2019 \\
\hline SAVR vs TAVR & Hunter Mehaffey & $\begin{array}{l}\text { Vinod Thourani and Kevin } \\
\text { Accola }\end{array}$ & $\begin{array}{l}\text { Washington Hospital Center } \\
\text { and AdventHealth }\end{array}$ & May 11, 2019 \\
\hline Past presidents & John Trahanas & Sundt, Cameron and Mathisen & $\begin{array}{l}\text { Massachusetts General } \\
\text { Hospital }\end{array}$ & May 11, 2019 \\
\hline Wellness in training & Jessica Luc & Mara Antonoff & $\begin{array}{l}\text { University of British } \\
\text { Columbia/MD Anderson }\end{array}$ & May 23, 2019 \\
\hline Pleural effusion/empyema & Dongning Zhang & Jonathan D'Cunha & University of Pittsburgh & May 31, 2019 \\
\hline Norwood vs hybrid & Garrett Coyan & $\begin{array}{l}\text { Mahesh Sharma And Richard } \\
\text { Ohye }\end{array}$ & $\begin{array}{l}\text { University of Pittsburgh, } \\
\text { University of North } \\
\text { Carolina, and University of } \\
\text { Michigan }\end{array}$ & June 5, 2019 \\
\hline
\end{tabular}


TABLE E2. Continued

\begin{tabular}{|c|c|c|c|c|}
\hline Name of podcast & Trainee author & Faculty author & Institution & Date \\
\hline RV failure with LVAD & Jared Beller & Leora Yaboro & University of Virginia & June 13, 2019 \\
\hline CT surgery ethics forum & Jason Han & Robert Sade & $\begin{array}{l}\text { University of Pennsylvania/ } \\
\text { Medical University of } \\
\text { South Carolina }\end{array}$ & July 10, 2019 \\
\hline AF ablation & Jason Han & Armin Kiankhooy & $\begin{array}{l}\text { University of Pennsylvania/ } \\
\text { University of Southern } \\
\text { California }\end{array}$ & September 18, 2019 \\
\hline Superior sulcus tumor & Miro Peev & Jessica Donington & University of Chicago & November 5, 2019 \\
\hline Re-do antireflux surgery & Chigozirim Ekeke & James Luketich & University of Pittsburgh & November 9, 2019 \\
\hline Robotic cardiac surgery & Osman Hashmi & Clifton Lewis & $\begin{array}{l}\text { University of Alabama } \\
\text { Birmingham }\end{array}$ & November 15, 2019 \\
\hline CABG conduits & Tomi Obafemi & Jack Boyd & Stanford University & March 11, 2020 \\
\hline Achalasia & Andrew Feczko & Siva Raja & Cleveland Clinic & March 29, 2020 \\
\hline Myxoma & Simran Randhawa & Puja Kachroo & Washington University & April 9, 2020 \\
\hline Pandemic ethics & David Blitzer & Robert Sade & $\begin{array}{l}\text { Medical University of South } \\
\text { Carolina }\end{array}$ & April 26, 2020 \\
\hline COVID-19 training & Ben Smood & Ara Vaporciyan & $\begin{array}{l}\text { University of Texas MD } \\
\text { Anderson }\end{array}$ & April 26, 2020 \\
\hline Mediastinal staging & Mujtaba Mubashir & Monisha Sudarshan & Cleveland Clinic & June 22, 2020 \\
\hline VV ECMO & Ankit Dhamija & J.W. Awori Hayanga & West Virginia University & July 2, 2020 \\
\hline Sleeve lobectomy & Phil Moonsamy & Doug Mathisen & $\begin{array}{l}\text { Massachusetts General } \\
\text { Hospital }\end{array}$ & July 3,2020 \\
\hline $\begin{array}{l}\text { Minimally invasive } \\
\text { congenital heart surgery }\end{array}$ & Clauden Louis & Joseph Turek & Duke University & July 9,2020 \\
\hline
\end{tabular}

